\title{
ANALISIS PERSEPSI PEMILIK DAN KONTRAKTOR TERHADAP PEMBAGIAN RESIKO DALAM KONTRAK UNIT PRICE
}

\author{
Oleh : Indra Suharyanto ${ }^{1}$ \\ E-mail: indrasuharyanto@gmail.com
}

\begin{abstract}
ABSTRAK: Kontrak Unit price adalah salah satu jenis kontrak dengan harga tetap. Pemakaian Kontrak Unit price dalam kondisi ekonomi yang tidak stabil cenderung banyak menimbulkan banyak resiko. Dari pemikiran tersebut, tujuan dari penelitian ini untuk mengetahui persepsi pemilik dan kontraktor terhadap pembagian resiko dalam Kontrak Unit price, yang mengacu pada sumber sumber terjadinya resiko berdasarkan syarat - syarat kontrak. Sumber - sumber terjadinya resiko yang diteliti adalah Lingkungan dan Site Acces, Syarat - syarat Kontrak, Desain dan Perencanaan, Pekerjaan Konstruksi, Perusahaan, Finansial, Masalah Politik, Ekonomi, Sosial, Logistik dan Force Majeure.

Pengumpulan data dilakukan dengan menyebarkan kuesioner dan wawancara secara acak di lima Kabupaten / Kota Madya di Propinsi Daerah Istimewa Yogyakarta. Kuesioner yang berhasil dikumpulkan sebanyak 29 responden terdiri dari 13 responden pemilik yang diwakili oleh DPU dan 16 responden kontraktor. Persepsi mengenai pembagian resiko dapat dilihat dari nilai means kelompok responden dan untuk menarik kesimpulan dilakukan uji statistik Mann Withney dengan hipotesis terhadap perbedaan persepsi dalam pembagian resiko.
\end{abstract}

Kata-kata kunci : persepsi, pembagian, resiko, kontrak unit price

\section{PENDAHULUAN}

\subsection{Latar Belakang}

Dalam kondisi perekonian yang tidak stabil dengan ditandai masih terfluktuasinya mata uang rupiah terhadap dollar. Hal ini diakibatkan oleh sentimen pasar terhadap kondisi dalam negeri, dalam masalah keamanan maupun kebijakan ekonomi makro. Dengan kondisi yang tidak menguntungkan ini, Industri Konstruksi seperti juga induntri yang lainnya merupakan kegiatan yang mengandung resiko tinggi dari permulaan sampai akhir kegiatan. Resiko ini timbul dari harga bahan yang berubah-ubah, kerusuhan/keamanan dan masalah pendanaan yang pada akhirnya akan mempengaruhi waktu, biaya dan kualitas hasil pekerjaan.

\subsection{Rumusan Masalah}

Dari latar belakang dia atas, rumusan masalah dalam peneltian ini adalah bagaimana persepsi pemilik (owner) dan kontraktor terhadap pembagian resiko dalam Kontrak Unit price.

\subsection{Batasan Masalah}

Untuk memahami permasalahan batasan-batasan yang digunakan adalah :

1. Daerah penelitian dibatasi hanya di wilayah Propinsi Daerah Istimewa Yogyakata yang meliputi Pemerintah Kota Yogyakarta, Kabupaten Sleman, Kabupaten Bantul, Kabupaten Gunung Kidul dan Kabupaten Kulon Progo.

1) adalah staf pengajar Program Studi Teknik Sipil Universitas Cokroaminoto Yogyakarta

20 Analisis Persepsi Pemilik dan Kontraktor Terhadap Pembagian Resiko dalam Kontrak Unit Price (Indra Suharyanto) 
2. Penelitian dilakukan pada proyek-proyek yang menjadi tanggung jawab Departemen Pekerjaan Umum, Pihak pemilik terbatas pada lingkungan instansi pemerintah yaitu Departemen Pekerjaan Umum (Bina Marga dan Pengairan), pihak kontraktor terbatas yang memiliki DRT dan DRM dengan Kualifikasi C1, sedang mengerjakan proyek pada lingkungan instansi pemerintah serta pada level site manager, projec manager, staf teknik dan pengawas proyek.

\subsection{Tujuan dan Manfaat}

Tujuan penelitian ini adalah untuk mengetahui persepsi pemilik dan kontraktor terhadap pembagian resiko dalam kontrak unit price dengan manfaat antara lain :

1. Perkembangan ilmu pengetahuan : dapat memberikan pengetahuan dan wawasan terhadap ilmu pengetahuan manajemen konstruksi terutama dalam bidang kontrak jasa konstruksi.

2. Jasa konstruksi : sebagai masukan dan informasi yang dapat digunakan, diterapkan dalam pengambilan keputusan serta penyusunan kontrak.

\section{TINJAUAN PUSTAKA}

\subsection{Umum}

Dalam dunia konstruksi terdapat dua pihak yaitu pihak prinsipal / client dan pihak agen. Pihak prinsipal merupakan pihak yang menghendaki adanya suatu bangunan sedangkan pihak agen adalah pihak yang melakukan sejumlah aktifitas dalam proses pembuatan bangunan. Yang termasuk pihak prinsipal antara lain departemen pemerintah atau perusahaan dan yang termasuk agen antara lain arsitek, engineer, surveyor, general kontraktor, konsultan, sub kontraktor dan suplier.

Menurut Flanagan dan Norman (1993) client industri konstruksi berdasarkan sumber pendanaan proyek dibagi dalam 2 kelompok yaitu public sector dan private sector. Pengertian dan kebutuhan client dikelompokkan menjadi 4 yaitu :

1. Memberikan pelayanan dan memproduksi barang, seperti pabrik dan perkantoran.

2. Memperbaiki atau menambah infrastruktur ekonomi, seperti pembuatan jalan dan pengelolaan limbah.

3. Kepentingan sosial, seperti rumah sakit dan tempat ibadah

4. Investasi yang dapat langsung digunakan, seperti rumah tinggal. 


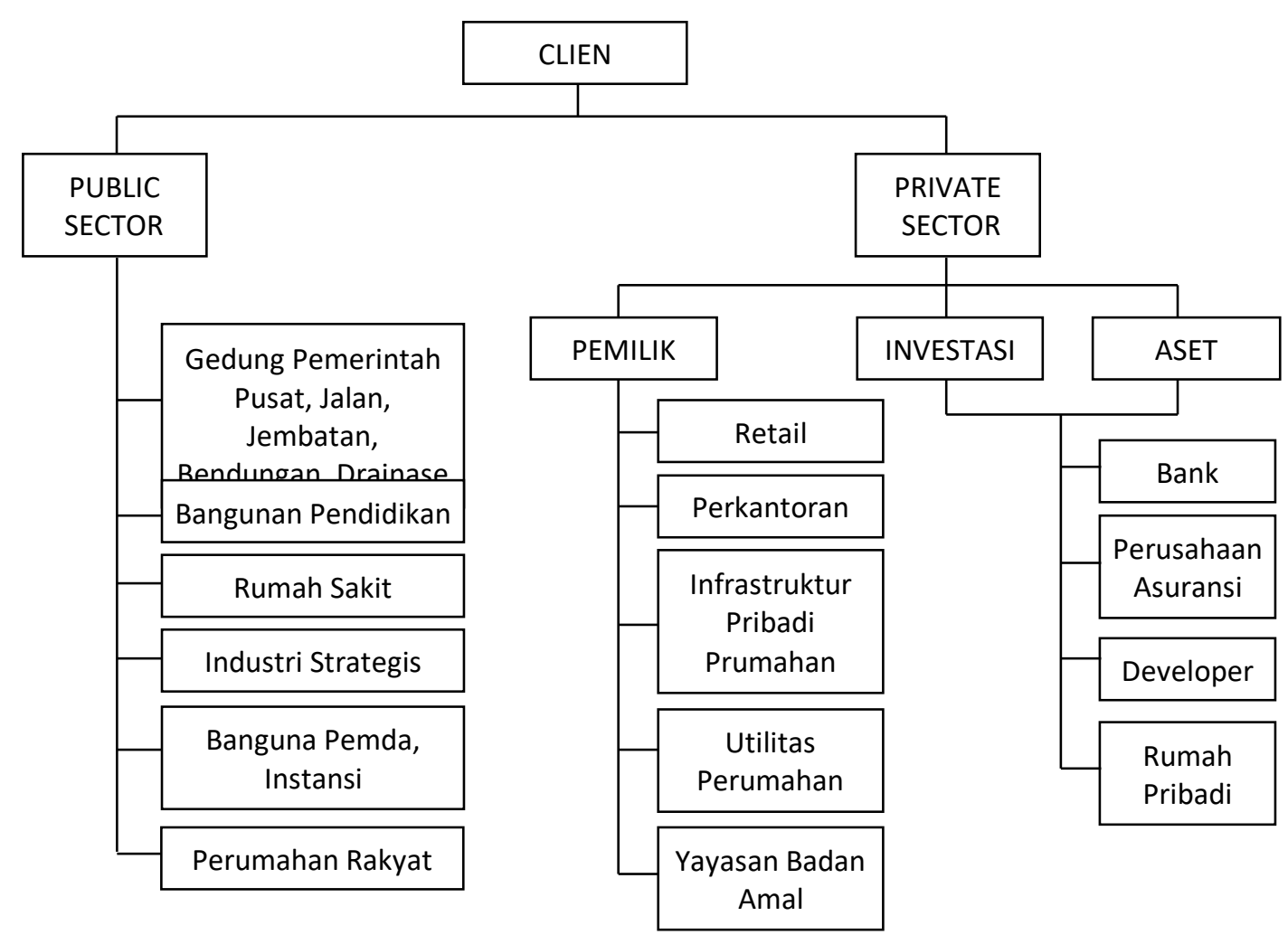

Gambar 1. Client Konstruksi Berdasar Pada Sumber Pendanaannya 

Sumber : Flanagan dan Norman (1993), Risk Management and Construction, Blackwell Science

Menurut Hinze (1993) sumber pendanaan pada private project adalah :

1. Pendanaan yang berdasar modal (capital) sendiri

2. Pinjaman langsung pihak kreditor

3. Penjualan aset yang dimiliki

4. Penjualan saham

5. Jaminan perusahaan

6. Donatur,

Sedangkan pada public project sumber pendanaan berasal dari :

1. Biaya opersional tahunan

2. Pajak

3. Jaminan yang dikeluarkan untuk tujuan tertentu

4. Dunatur

\subsection{Resiko}

\section{A. Ketidak pastian, Opportunity Dan Resiko}

Ketidak pastian dapat diartikan suatu kondisi kurangnya keakuratan dan kelengkapan data tentang situasi yang harus dipertimbangkan dalam pengambilan keputusan. Perusahaan beroperasi dalam lingkungan dimana terjadi benyak ketidak pastian sehingga harus mengidentifikasi, menganalisa, mengevaluasi dan beroperasi dengan suatu resiko tertentu.

Secara umum resiko dalam suatu proyek konstruksi berhubungan dengan :

1. Kegagalan dalam mempertahankan cost budget/forecast/estimate/tender

2. Kegagalan dalam memenuhi waktu yang telah ditetapkan dalam kontrak

3. Kegagalan dalam memenuhi standar teknis dalam hal kualitas, fungsi, tujuan, keselamatan dan lingkungan

Kurangnya pemahaman mengenai situasi yang akan terjadi dapat menjadi suatu keuntungan atau menjadi kerugian. Menjadi keuntungan karena merupakan kesempatan (opportunity) dan merugikan karena mengandung resiko yang harus ditanggung. Ketidak pastian, opportunity dan resiko merupakan satu kesatuan seperti pada gambar berikut :

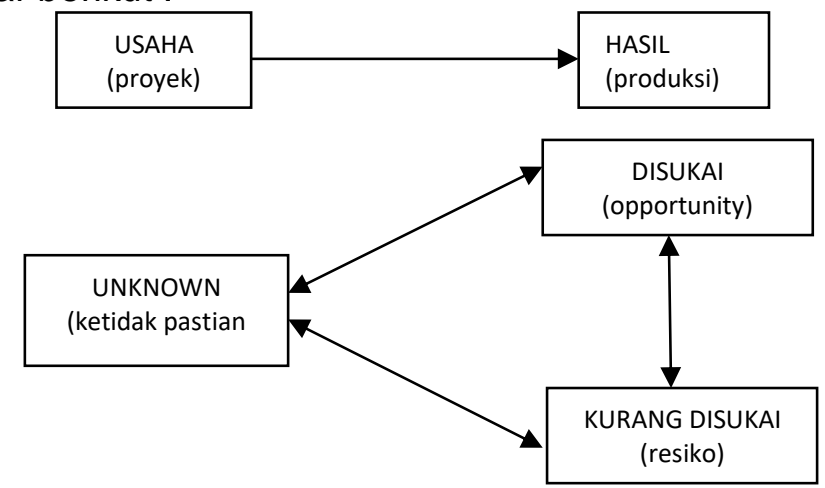

Gambar 2. Hubungan Ketidak pastian, Opportunity dan Resiko

Sumber : Wideman (1992), Project and Programm Risk Management A Guide To

Managing Project Risk and Opportunity , Project Management and Institute, hal. I-3

Wideman (1992) mengatakan bahwa resiko dapat disebabkan oleh faktor-faktor :

Eksternal yang kurang, Eksternal dan dapat diprediksi tapi kurang dapat

dikontrol, Internal yang bersifat non teknis tapi biasanya dapat dikontrol, Legal

dan biasanya dapat dikontrol 


\section{B. Manajemen Resiko}

Manajemen resiko memberikan beberapa konsep utama yaitu meminimalkan resiko tanpa memperhaikan siapa yang mempunyai resiko dan pembagian resiko yang adil diantara pihak penyelenggara proyek. Manajemen resiko tidak digunakan untuk menghilangkan resiko yang ada pada suatu proyek tetapi bertujuan untuk menjamin resiko yang ada dapat diantisipasi dan dikendalikan seefisien mungkin.

Tujuan dari manajemen resiko adalah :

1. Mengidentifikasikan secara spesifik faktor-faktor kemungkinan yang mempengaruhi scope, quality, time dan cost suatu proyek

2. Menghitung pengaruh dari masing-masing faktor kemungkinan

3. Memberikan acuan tentang hal-hal yang tidak dapat dikontrol pada suatu proyek

4. Mengurangi dampak dengan memberikan perhatian dan tindakan terhadap segala hal yang dapat dikontrol

Pemahaman mengenai manajemen resiko dapat digambarkan berikut :

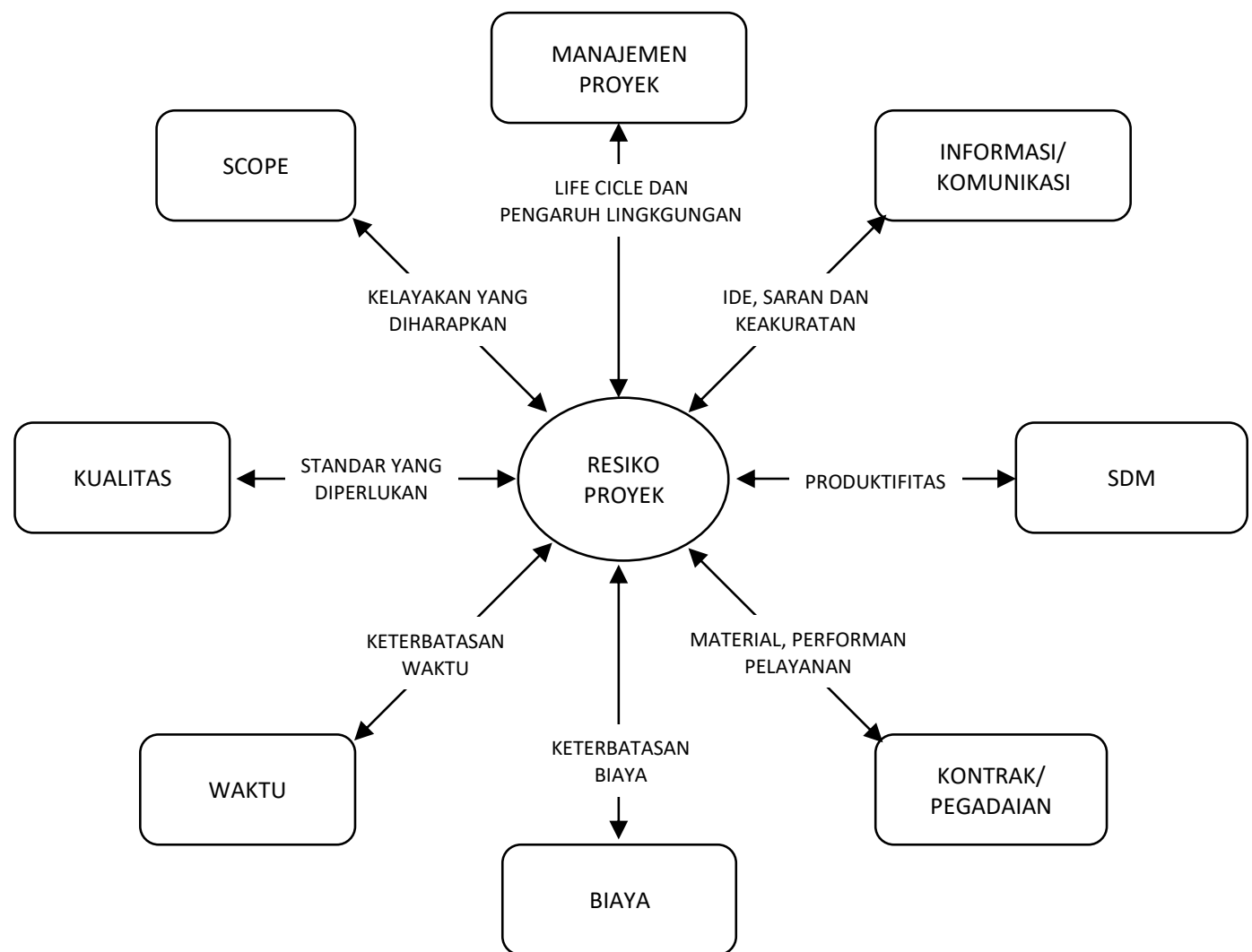

Gambar 3. Resiko Yang Terdapat Pada Manajemen Proyek

Sumber : Wideman (1992), Project and Programm Risk Management A Guide To Managing Project Risk and Opportunity, Project Management and Institute, hal. II-2

\subsection{Kontrak}

\section{A. Aspek Hukum Kontrak Konstruksi}

Kontrak yang dibuat dinyatakan sah secara hukum apabila memenuhi 4 (empat) aspek dalam Pasal 1320 KUHP Perdata yaitu : 
1. Adanya kata sepakat

2. Dibuat oleh pihak yang cakap

3. Adanya objek tertentu

4. Adanya sebab yang halal

Syarat pertama dan ke-dua merupakan syarat subyektif karena berkaitan erat dengan kontrak tersebut, sedangkan syarat ke-tiga dan ke-empat merupakan syarat obyektif.

B. Kontrak Konstruksi

Dalam kontrak konstruksi , suatu kontrak dikatakan telah dilaksanakan apabila pihak tertentu telah mengerjakan kewajibannya seperti yang terdapat dalam dokumen kontrak dan telah dibayar semua pekerjaannya. Kontrak dapat dikelompokkan dalam berbagai cara, diantaranya berdasarkan atas jenis pekerjaan, yaitu : kontrak lump sum, kontrak unit price dan kontrak cost plus. Kontrak lump sum digunakan pada proyek dimana terdapat kejelasan jumlah item dan kuantitasnya, kontrak unit price digunakan pada proyek dimana masing-masing pihak tidak dapat menentukan secara tepat kuantitas item pekerjaan yang akan dilaksanakan, sedangkan kontrak cost plus digunakan pada proyek dengan ketidak jelasan jumlah item pekerjaan dan kuantitasnya.

Pada industri konstruksi terdapat 5 (lima) metode dasar dalam penyusunan kontrak (Hinze, 1993), yaitu :.

1. General Control Method

Sebuah kontrak yang disusun oleh owner dan general contractor. Dalam penyusunan kontrak ini dapat mewakilkan pada sebuah perusahaan tertentu. Untuk pekerjaan public sector peran dan tugas masing-masing pihak didefinisikan secara jelas dan mengikuti semua prosedur standar yang berlaku, mulai dari tahapan undangan pada kontraktor untuk mengikuti lelang suatu pekerjaan sampai dengan tahapan penentuan pemenang lelang. Sedangkan pada pekerjaan private sector, prosedur yang digunakan hampir sama dengan pekerajaan public sector, hanya dalam penerapannya lebih luwes misalnya dalam hal pemberitahuan/undangan kepada kontraktor, dapat hanya terbatas pada kontraktor yang dikenal baik oleh owner.

2. Seprate contract method

Dalam kontrak ini owner melakukan suatu persetujuan dengan beberapa kontraktor spesialis sehingga tidak memerlukan general contractor. Pada kontrak ini diasumsikan owner memiliki kemampuan dalam hal manajemen konstruksi.

3. Force acount method

Force acount method merupakan sebuah mekanisme dimana tidak terdapat kontrak dalam pekerjaan konstruksi. Owner memilki sekelompok pekerja sendiri. Kondisi ini sering terjadi pada proyek-proyek kecil yang tidak memerlukan prosedur dan organisasi yang rumit.

4. Design contract method

Owner membuat suatu kesepakatan/kontrak dengan suatu pihak tertentu diman pihak tersebut bertanggung jawab untuk tahapan desain sampai dengan tahapan konstruksi.

5. Profesional construction management method

Owner menyewa seorang Construction Manager $(C N)$ untuk menyelesaikan proyek. Construction Manager tersebut biasanya disewa sebelum tahapan desain dan konstruksi dimulai disertai tanggung jawab untuk mengendalikan proyek mulai dari tahap desain sampai tahapan konstruksi. 


\subsection{Kontrak Unit Price}

Kontrak unit price berdasar pada harga total penawaran dimana penetapan harga dari harga satuan yang tercantum pada dokumen penawaran. Harga satuan unit price merupakan harga rata-rata per-unit item pekerjaan. Nilai sebuah item pekerjaandidapatkan dari kuantitas item pekerjaan dikalikan dengan harga satuannya. Kontrak jenis ini cocok pada proyek dengan kuantitas aktual dari tiap item yang sulit ditetapkan secara pasti. Harga satuan dari sebuah item pekarjaan tidak selalu sama untuk setiap proyek karena dipengaruhi oleh faktor-faktor antara lain : lokasi, jenis pekarjaan, kebiasaan. Harga satuan cenderung lebih randah pada kuantitas yang besar karena tingkat efisiensi lebih tinggi.

Keuntungan owner pada sistem kontrak ini adalah dapat menyelesaikan proyek dengan resiko minimal walaupun owner tidak dapat menentukan secara tepat banyaknya pekerjaan dan dan besarnya dana yang harus disediakan. Keuntungan kontraktor adalah mendapat pembayaran berdasar atas nilai pekerjaan, sedangkan kerugian kontraktor adalah tidak dapat mengetahui secara tepat dana yang harus disediakan untuk menyelesaikan pekerjaan.

\section{METODOLOGI PENELITIAN}

\subsection{Populasi dan Sampel}

Populasi pada penelitian ini adalah seluruh kontraktor yang menjadi rekanan DPU dengan klasifikasi $C$ dan owner diwakili oleh Departemen Pekerjaan Umum se DIY, antara lain : Dinas Kimpraswil Kota Yogyakarta, DPU Kabupaten Sleman, DPU Kabupaten Gunung Kidul, DPU Kabupaten Kulon Progo dan DPU Kabupaten Bantul. Waktu penelitian pada tahun 2003 sampai 2005 dengan jumlah sampel ada 29 yang terdiri dari 16 kontraktor dan 13 pemilik yang diwakili oleh Departemen Pekerjaan Umum.

\subsection{Metode Pengumpulan Data}

Metode yang digunakan dalam pengambilan sampel adalah ramdom sampling atau sampel acak yang terdiri dari 2 (dua) jenis data, yaitu :

1. Data Primer, adalah data lengsung yang didapat dari responden dengan cara melalui daftar pertanyaan atau kuesioner. Bentuk pertanyaan kepada responden ada dua yaitu pertanyaan dari karakteristik dari responden dan pertanyaan mengenai pembagian resiko. Kedua kelompok pertanyaan tersebut bersifat tertutup

2. Data Sekunder, adalah data untuk mengisi kebutuhan akan rujukan khusun pada beberapa hal. Data sekunder membantu memutuskan kebutuhan penelitian yang perlu dilakukan.

\subsection{Variabel Penelitian}

Variabel penelitian dibagi menjadi dua bagian, yaitu : data responden dan pertanyaan pembagian resiko yang terdapat pada kontrak unit price.

1. Data Responden

a. Latar belakang yang meliputi jabatan, umur pengalaman dan tingkat pendidikan

b. Posisi yang diwakili dalam klausa kontrak

c. Lokasi proyek

d. Kualifikasi pekerjaan

e. Nilai total proyek

f. Sumber dana

Analisis persepsi kontraktor dan owner dalam pembagian resiko pada proyek unit price didasarkan atas variabel berikut : 
2. Alokasi resiko klausa kontrak unit price Analisis persepsi kontraktor dan owner dalam pembagian resiko pada proyek unit price didasarkan atas variabel berikut:

a. Lingkungan dan site acces meliputi cuaca, kesulitan akses dan keamanan

b. Syarat-syarat kontrak meliputi kegagalan serta hubungan yang salah dalam kontrak, terjadinya pembengkakan biaya

c. Desain dan perencanaan meliputi cacat mutu, desain yang salah serta adanya perbedaan dalam penetapan volume pekerjaan

d. Perusahaan meliputi organisasi dan peran manajer

e. Logistik meliputi kebijaksanaan pemerintah dan kesulitan pendaan

f. Politik, sosial dan ekonomi

g. Force majaure meliputi bencana alam dan kebakaran

\section{ANALISA DATA}

Pengambilan data dengan cara membagikan pertanyaan/kuesioner kepada 50 responden dalam wilayah 4 kabupaten dan 1 kota madya se DIY pada bulan Agustus 2005 selama 1 bulan. Jawaban yang dikumpulkan kembali sebanyak 29 terdiri dari 13 dari pihak pemilik dan 16 dari pihak kontraktor.

\subsection{Karakteristik Data}

\section{A. Profil Responden}

Profil responden disajikan dalam tabel-tebel berikut

Tabel 1. Jabatan Responden

\begin{tabular}{|c|l|r|c|}
\hline No. & \multicolumn{1}{|c|}{ Jabatan Responden } & Jumlah & Persentasi (\%) \\
\hline 1. & Pimpinan Proyek (Pemilik) & 6 & 20,69 \\
\hline 2. & Kepala Proyek/Staf Teknik (Kontraktor) & 13 & 44,83 \\
\hline 3. & Lain-lain Jumlah & 10 & 44,48 \\
\hline & \multicolumn{2}{|c|}{29} & 100,00 \\
\hline
\end{tabular}

Tabel 2. Tingkat Pengalaman Responden

\begin{tabular}{|c|c|r|c|}
\hline No. & Pengalaman Responden & Jumlah & Persentasi (\%) \\
\hline 1. & $<5$ tahun & 6 & 20,69 \\
\hline 2. & $5-15$ tahun & 14 & 48,27 \\
\hline 3. & $>15$ tahun Jumlah & 9 & 31,03 \\
\hline & \multicolumn{2}{|c|}{29} & 100,00 \\
\hline
\end{tabular}

Tabel 3. Tingkat Pendidikan Responden

\begin{tabular}{|c|c|c|c|}
\hline No. & Pendidikan Responden & Jumlah & Persentasi (\%) \\
\hline 1. & $<$ SLTA & 2 & 6,90 \\
\hline 2. & D3 & 4 & 13,79 \\
\hline 3. & S1 & 21 & 72,41 \\
\hline 4 & $>\mathrm{S} 1$ & 2 & 6,90 \\
\hline & Jumlah & 29 & 100,00 \\
\hline
\end{tabular}

\section{B. Profil Proyek}

Profil proyek disajikan dalam tabel berikut

Tabel 4. Nilai Proyek Konstruksi

\begin{tabular}{|c|c|c|c|}
\hline No. & Nilai Proyek Konstruksi & Jumlah & Persentasi (\%) \\
\hline 1. & $<1$ milyar & 7 & 24,14 \\
\hline 2. & $1-10$ milyar & 12 & 41,38 \\
\hline 3. & $>10$ milyar Jumlah & 10 & 34,48 \\
\hline & \multicolumn{2}{|c|}{29} & 100,00 \\
\hline
\end{tabular}

26 Analisis Persepsi Pemilik dan Kontraktor Terhadap Pembagian Resiko dalam Kontrak Unit Price (Indra Suharyanto) 


\subsection{Alokasi Pembagian Resiko Dalam Kontrak Unit price}

Kontrak unit price adalah satu bentuk ikatan kontrak atau kesepakatan antara pemilik/owner dengan kontraktor dan konsultan dan sering digunakan pada proyekproyek di lingkungan Departemen Pekerjaan Umum dalam industri jasa konstruksi yang. Para pelaku industri konstruksi dapat menannggung beban resiko yang

berbeda-beda. Resiko terjadi akibat kesalahan dari pihak tertentu di dalam proyek (internal proyek) atau dari pihak eksternal proyek yang berdampak langsung atau tidak langsung terhadap kinerja proyek. Pihak yang melakukan kesalahan akan menanggung beban resiko terbesar, sedangkan seriko karena faktor eksternal akan manjadi tanggug jawab bersama dengan porsi tertentu. Besar tanggungan resiko pada setiap sumber resiko yang ditanggung pelaku industri konstruksi akan berbeda.

\section{A. Persepsi Pemilik}

Tabel 5. Persepsi Resiko Menurut Pemilik

\begin{tabular}{|c|c|c|c|c|c|c|c|c|}
\hline \multirow{2}{*}{ No } & \multirow{2}{*}{ Sumber Resiko } & \multicolumn{5}{|c|}{ Skala Resiko } & \multirow{2}{*}{$\begin{array}{c}\text { Mean } \\
\text { Variabel }\end{array}$} & \multirow{2}{*}{$\begin{array}{c}\text { Mean } \\
\text { Kelompok }\end{array}$} \\
\hline & & 1 & 2 & 3 & 4 & 5 & & \\
\hline \multirow[t]{5}{*}{1.} & Lingkungan & & & & & & & \multirow{5}{*}{3,0385} \\
\hline & Masalah cuaca & 0 & 0 & 1 & 9 & 3 & 4,1538 & \\
\hline & Kesulitan akses ke lokasi & 0 & 3 & 3 & 4 & 3 & 3,5384 & \\
\hline & Akibat pembebasan tanah & 4 & 3 & 6 & 0 & 0 & 2,2538 & \\
\hline & Keamanan proyek & 4 & 2 & 6 & 1 & 0 & 2,3077 & \\
\hline \multirow[t]{5}{*}{2.} & Syarat-Syarat Kontrak & & & & & & & \multirow{5}{*}{2,9808} \\
\hline & Gagal dokumen kontrak & 0 & 3 & 6 & 4 & 0 & 3,0769 & \\
\hline & Tidak cocok dokumen kontrak & 1 & 5 & 6 & 1 & 0 & 2,5385 & \\
\hline & Hubungan yang salah & 1 & 0 & 12 & 0 & 0 & 2,6842 & \\
\hline & Pembengkakan biaya & 2 & 1 & 1 & 7 & 2 & 3,4615 & \\
\hline \multirow[t]{5}{*}{3.} & Desain Dan Perencanaan & & & & & & & \multirow{5}{*}{2,6731} \\
\hline & Kurang memahami kontrak & 1 & 4 & 2 & 6 & 0 & 3,0000 & \\
\hline & Salah perumusan desain \& spesifikasi & 2 & 5 & 3 & 2 & 1 & 2,6154 & \\
\hline & Cacat mutu & 2 & 4 & 3 & 4 & 0 & 2,6923 & \\
\hline & Beda penerapan besar volume pekerjaaj & 1 & 6 & 6 & 0 & 0 & 2,3846 & \\
\hline \multirow[t]{7}{*}{4.} & Pekerjaan Konstruksi & & & & & & & \multirow{7}{*}{4,1410} \\
\hline & Ketidak akuratan mengenai kondisi & 1 & 4 & 4 & 3 & 1 & 2,9231 & \\
\hline & Produktifitas tenaga kerja rendah & 1 & 0 & 1 & 6 & 5 & 4,0769 & \\
\hline & Pelaksanaan standar keselamatan kerja & 0 & 0 & 1 & 5 & 7 & 4,4615 & \\
\hline & Kecelakaan kerja & 0 & 0 & 1 & 3 & 10 & 4,6923 & \\
\hline & Pemogokan & 0 & 0 & 3 & 4 & 5 & 4,1538 & \\
\hline & Kerusakan peralatan kerja & 0 & 0 & 1 & 4 & 8 & 4,5385 & \\
\hline \multirow[t]{4}{*}{5.} & Perusahan & & & & & & & \multirow{4}{*}{3,6667} \\
\hline & Organisasi perusahaan jelek & 1 & 1 & 1 & 6 & 4 & 3,8462 & \\
\hline & Otoritas manajemen besar & 1 & 1 & 2 & 5 & 4 & 3,7692 & \\
\hline & Pengalaman kerja kurang & 1 & 2 & 4 & 3 & 3 & 3,3846 & \\
\hline \multirow[t]{6}{*}{6.} & Logistik & & & & & & & \multirow{6}{*}{4,0462} \\
\hline & Keterbatasan jenis material & 0 & 0 & 4 & 7 & 2 & 3,8462 & \\
\hline & Fluktuasi harga material & 0 & 0 & 5 & 5 & 3 & 3,8462 & \\
\hline & Gangguan sirkulasi & 0 & 0 & 0 & 10 & 3 & 4,2308 & \\
\hline & Tenaga kerja berkualitas kurang & 0 & 0 & 1 & 8 & 4 & 4,2308 & \\
\hline & Suku cadang peralatan sulit & 0 & 0 & 2 & 8 & 3 & 4,0769 & \\
\hline \multirow[t]{6}{*}{7.} & Finansial & & & & & & & \multirow{6}{*}{2,9077} \\
\hline & Kebijaksanaan ekonomi berubah-ubah & 0 & 2 & 8 & 1 & 2 & 3,2308 & \\
\hline & Hubungan antar donatur jelek & 3 & 5 & 4 & 1 & 0 & 2,2308 & \\
\hline & Kesulitan pendanaan pemilik & 6 & 4 & 3 & 1 & 0 & 1,8462 & \\
\hline & Kontraktor kurang modal & 1 & 0 & 1 & 4 & 7 & 4,2308 & \\
\hline & Kesulitan pendanaan akibat eksternal & 0 & 2 & 9 & 2 & 0 & 3,0000 & \\
\hline \multirow[t]{4}{*}{8.} & Politik, Sosial, Ekonomi & & & & & & & \multirow{4}{*}{2,6154} \\
\hline & Kerusakan, perang dan pemberontakan & 3 & 2 & 8 & 0 & 0 & 2,3846 & \\
\hline & Keterlambatan birokrasi & 2 & 5 & 4 & 2 & 0 & 2,4615 & \\
\hline & Kondisi ekonomi yang belum baik & 0 & 2 & 9 & 2 & 0 & 3,0000 & \\
\hline 9. & Force Majeure & & & & & & & \\
\hline & Akibat bencana alam & 4 & 1 & 8 & 0 & 0 & 2,3077 & 2,6538 \\
\hline & Kebakaran & 2 & 7 & 4 & 0 & 0 & 3,0000 & \\
\hline
\end{tabular}


Grafik 1. Pembagian Resiko Menurut Pemilik

\begin{tabular}{|c|c|c|c|c|c|c|c|c|}
\hline \multicolumn{9}{|c|}{ - SKALA RESIKO MENURUT PEMILIK } \\
\hline 3,0385 & 2,9808 & 26731 & 4,1410 & 3,6667 & 4,0462 & 2,9077 & 26154 & 26538 \\
\hline 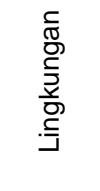 & 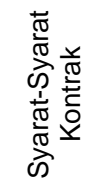 & 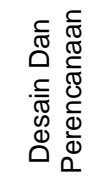 & 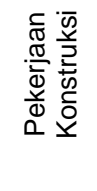 & 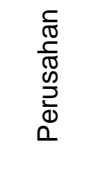 & 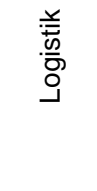 & 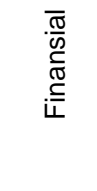 & 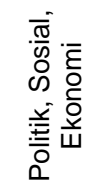 & 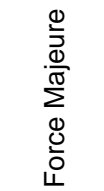 \\
\hline
\end{tabular}

\section{B. Persepsi Kontraktor}

Tabel 6. Persepsi Resiko Menurut Kontraktor

\begin{tabular}{|c|c|c|c|c|c|c|c|c|}
\hline \multirow{2}{*}{ No } & \multirow{2}{*}{ Sumber Resiko } & \multicolumn{5}{|c|}{ Skala Resiko } & \multirow{2}{*}{$\begin{array}{c}\text { Mean } \\
\text { Variabel }\end{array}$} & \multirow{2}{*}{$\begin{array}{c}\text { Mean } \\
\text { Kelompok }\end{array}$} \\
\hline & & 1 & 2 & 3 & 4 & 5 & & \\
\hline \multirow[t]{5}{*}{1.} & Lingkungan & & & & & & & \multirow{5}{*}{2,8954} \\
\hline & Masalah cuaca & 0 & 0 & 9 & 5 & 2 & 3,5625 & \\
\hline & Kesulitan akses ke lokasi & 3 & 3 & 3 & 5 & 2 & 3,0000 & \\
\hline & Akibat pembebasan tanah & 5 & 5 & 2 & 1 & 0 & 1,9375 & \\
\hline & Keamanan proyek & 2 & 8 & 4 & 5 & 1 & 2,9375 & \\
\hline \multirow[t]{5}{*}{2.} & Syarat-Syarat Kontrak & & & & & & & \multirow{5}{*}{3,2813} \\
\hline & Gagal dokumen kontrak & 0 & 3 & 2 & 7 & 4 & 3,7500 & \\
\hline & Tidak cocok dokumen kontrak & 1 & 4 & 4 & 6 & 1 & 3,1250 & \\
\hline & Hubungan yang salah & 0 & 7 & 3 & 4 & 2 & 3,0625 & \\
\hline & Pembengkakan biaya & 0 & 4 & 7 & 3 & 2 & 3,1825 & \\
\hline \multirow[t]{5}{*}{3.} & Desain Dan Perencanaan & & & & & & & \multirow{5}{*}{2,9844} \\
\hline & Kurang memahami kontrak & 1 & 2 & 0 & 9 & 4 & 3,8125 & \\
\hline & Salah perumusan desain \& spesifikasi & 3 & 5 & 2 & 6 & 0 & 2,6875 & \\
\hline & Cacat mutu & 2 & 8 & 2 & 2 & 2 & 2,6250 & \\
\hline & Beda penerapan besar volume pekerjaaj & 2 & 4 & 5 & 5 & 0 & 2,8125 & \\
\hline \multirow[t]{7}{*}{4.} & Pekerjaan Konstruksi & & & & & & & \multirow{7}{*}{3,9479} \\
\hline & Ketidak akuratan mengenai kondisi & 1 & 0 & 5 & 9 & 1 & 3,5625 & \\
\hline & Produktifitas tenaga kerja rendah & 0 & 1 & 2 & 8 & 5 & 4,0625 & \\
\hline & Pelaksanaan standar keselamatan kerja & 0 & 0 & 1 & 12 & 3 & 4,1250 & \\
\hline & Kecelakaan kerja & 1 & 0 & 0 & 11 & 4 & 4,0625 & \\
\hline & Pemogokan & 1 & 0 & 3 & 8 & 4 & 3,8750 & \\
\hline & Kerusakan peralatan kerja & 0 & 1 & 2 & 9 & 4 & 4,0000 & \\
\hline \multirow[t]{4}{*}{5.} & Perusahan & & & & & & & \multirow{4}{*}{3,6042} \\
\hline & Organisasi perusahaan jelek & 0 & 2 & 5 & 5 & 4 & 3,5625 & \\
\hline & Otoritas manajemen besar & 0 & 1 & 4 & 10 & 1 & 3,6875 & \\
\hline & Pengalaman kerja kurang & 1 & 2 & 5 & 4 & 4 & 3,5000 & \\
\hline \multirow[t]{6}{*}{6.} & Logistik & & & & & & & \multirow{6}{*}{3,7000} \\
\hline & Keterbatasan jenis material & 0 & 2 & 4 & 9 & 1 & 3,5625 & \\
\hline & Fluktuasi harga material & 1 & 2 & 6 & 5 & 2 & 3,3125 & \\
\hline & Gangguan sirkulasi & 0 & 2 & 4 & 8 & 3 & 3,8125 & \\
\hline & Tenaga kerja berkualitas kurang & 1 & 0 & 3 & 8 & 5 & 4,0000 & \\
\hline & Suku cadang peralatan sulit & 1 & 0 & 3 & 9 & 3 & 3,8125 & \\
\hline \multirow[t]{6}{*}{7.} & Finansial & & & & & & & \multirow{6}{*}{2,6375} \\
\hline & Kebijaksanaan ekonomi berubah-ubah & 5 & 4 & 5 & 1 & 1 & 2,3125 & \\
\hline & Hubungan antar donatur jelek & 6 & 4 & 3 & 2 & 1 & 2,2500 & \\
\hline & Kesulitan pendanaan pemilik & 7 & 2 & 4 & 3 & 0 & 2,1875 & \\
\hline & Kontraktor kurang modal & 1 & 3 & 1 & 6 & 5 & 3,6875 & \\
\hline & Kesulitan pendanaan akibat eksternal & 0 & 6 & 8 & 2 & 0 & 2,7500 & \\
\hline \multirow[t]{4}{*}{8.} & Politik, Sosial, Ekonomi & & & & & & & \multirow{4}{*}{2,4792} \\
\hline & Kerusakan, perang dan pemberontakan & 5 & 4 & 7 & 0 & 0 & 2,1250 & \\
\hline & Keterlambatan birokrasi & 2 & 8 & 2 & 3 & 1 & 2,5625 & \\
\hline & Kondisi ekonomi yang belum baik & 2 & 4 & 10 & 2 & 0 & 2,7500 & \\
\hline 9. & Force Majeure & & & & & & & \\
\hline & Akibat bencana alam & 5 & 5 & 6 & 0 & 0 & 2,0625 & 2,4792 \\
\hline & Kebakaran & 2 & 5 & 6 & 3 & 0 & 2,6250 & \\
\hline
\end{tabular}

\section{Grafik 2. Pembagian Resiko Menurut Kontraktor}

28 Analisis Persepsi Pemilik dan Kontraktor Terhadap Pembagian Resiko dalam Kontrak Unit Price (Indra Suharyanto) 


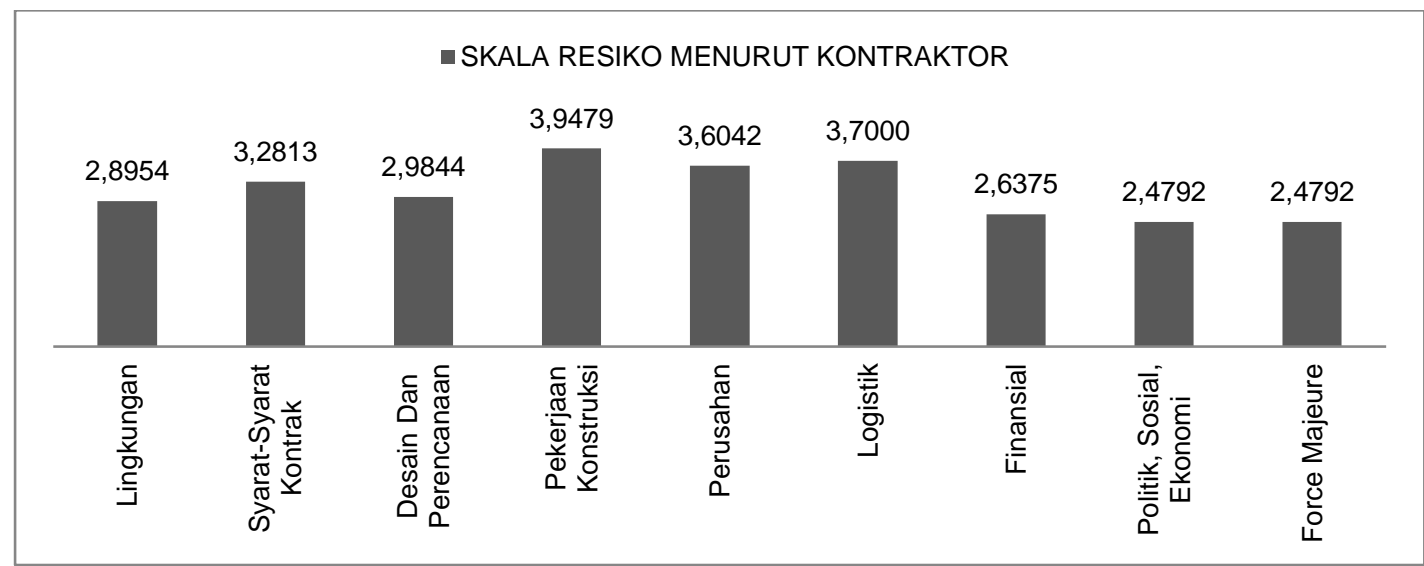

C. Persepsi antara Pemilik dan Kontraktor

Grafik 3. Pembagian Resiko Menurut Pemilik dan Kontraktor

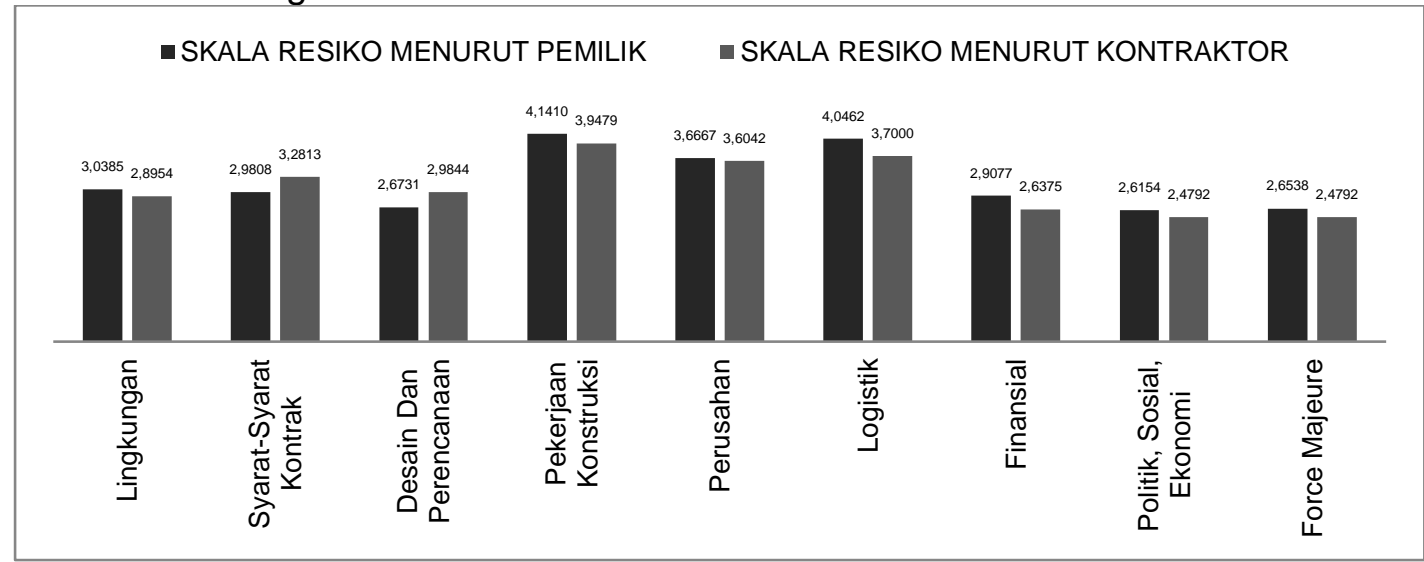

1. Persepsi pemilik

a. Resiko yang menjadi tanggung jawab pemilik adalah :

- Desain dan Perencanaan

- Politik, Sosial, Ekonomi

- Force Majeure

b. Resiko yang menjadi tanggung jawab kontraktor adalah :

- Pekerjaan Konstruksi

- Perusahaan

- Logistik

c. Resiko yang menjadi tanggung jawab bersama adalah :

- Lingkungan

- Syarat-syarat Kontrak

- Finansial

2. Persepsi kontraktor

a. Resiko yang menjadi tanggung jawab pemilik adalah :

- Finansial

- Politik, Sosial, Ekonomi

- Force Majeure

b. Resiko yang menjadi tanggung jawab kontraktor adalah :

- Perusahaan

- Logistik

- Syarat-syarat Kontrak

- Pekerjaan Konstruksi 
c. Resiko yang menjadi tanggung jawab bersama adalah :

- Lingkungan

- Desain dan Perencanaan

Dari dua persepsi pemilik dan kontraktor dalam pembagian resiko terhadap kontrak unit price terdapat perbedaan dalam melihat resiko desain perencanaan dan resiko finansial. Pemilik beranggapan resiko desain perencanaan menjadi tanggung jawab pemilik dan resiko finansial menjadi tanggung jawab bersama. Sedangkan kontraktor beranggapan resiko desain perencanaan menjadi tanggung jawab bersama dan resiko finansial menjadi tanggung jawab pemilik.

Pemilik dalam persepsinya mengenai resiko desain perencanaan didasarkan pertimbangan bahwa segala resiko yang timbul akibat kesalahan perencaan sebelum pekerjaan dilaksanakan menjadi tanggung jawabnya, hal ini ditegaskan dalam perjanjian kontrak kecuali terhadap desain perencaan sementara yang dibuat kontraktor. Dari pengalaman di lapangan kontraktor sering dihadapkan pada keputusan untuk merubah desain yang sesuai dengan kebutuhan, maka kontraktor beranggapan resiko desain perencanaan manjadi tanggung jawab bersama.

Pemilik dalam persepsinya mengenai resiko finansial beranggapan bahwa resiko finansial merupakan masalah yang diakibatkan oleh pendanaan, baik itu kesulitan pendanaan pihak pemilik maupun pihak kontraktor menjadi tanggung jawab bersama. Dalam setiap proses pelelangan kontraktor harus bisa menunjukkan bank yang mau menanggungnya sehingga kesulitan dari pihak kontraktor diakibatkan oleh ketidakmampuan pihak penjamin (bank garansi). Dalam mengajukan penawaran pihak kontraktor selalu memperhitungkan kemampuan pendanaannya, apabila merasa tidak mampu kontraktor tidak akan mengajukan penawaran. Dengan pemikiran itu maka kotraktor beranggapan resiko finansial menjadi tanggung jawab pemilik.

\section{Analisa Mann Withney-Perbedaan}

Dari dua persepsi pemilik dan kontraktor dalam pembagian resiko terhadap kontrak unit price, terdapat perbedaan dalam resiko desain perencanaan dan resiko finansial. Pemilik beranggapan resiko desain perencanaan menjadi tanggung jawab pemilik dan resiko finansial menjadi tanggug jawab bersama, sedangkan kontraktor beranggapan resiko desain perencanaan menjadi tanggung jawab bersama dan resiko finansial menjadi tanggung jawab pemilik. Untuk mengetahui apakah pemilik dan kontraktor dalam persepsinya mengenai pembagian resiko dalam kontrak unit price terdapat perbedaan atau tidak dilakukan uji Mann Withney

Tabel 7. Nilai Mean dan Sum Rank Uji Mann Withney

\begin{tabular}{|l|c|c|c|c|}
\hline \multirow{2}{*}{\multicolumn{1}{c|}{ Sumber Resiko }} & \multicolumn{2}{c|}{ Pemilik } & \multicolumn{2}{c|}{ Kontraktor } \\
\cline { 2 - 5 } & Mean & Sum Rank & Mean & Sum Rank \\
\hline Lingkungan & 3,0385 & 210,50 & 2,8954 & 224,50 \\
\hline Syarat-Syarat Kontrak & 2,9808 & 184,50 & 3,2813 & 250,50 \\
\hline Desain Dan Perencanaan & 2,6731 & 169,00 & 2,9844 & 266,00 \\
\hline Pekerjaan Konstruksi & 4,1410 & 229,50 & 3,9479 & 205,50 \\
\hline Perusahan & 3,6667 & 203,50 & 3,6042 & 231,50 \\
\hline Logistik & 4,0462 & 221,00 & 3,7000 & 214,50 \\
\hline Finansial & 2,9077 & 219,00 & 2,6375 & 216,00 \\
\hline Politik, Sosial, Ekonomi & 2,6154 & 209,00 & 2,4792 & 266,00 \\
\hline Force Majeure & 2,6538 & 217,00 & 2,4792 & 217,50 \\
\hline
\end{tabular}

Mann Withney $U=100,5 \quad Z=-0,154$ Asymp.Sig $=0,878$ Exact $\operatorname{Sig}=0,880$

Dari uji Mann Withney didapat nilai signifikan 0,880 yang berarti lebih besar dari nilai uji yang digunakan sebesar 0,05 maka pengujian ini dapat disimpulkan bahwa pemilik dan kontraktor dalam persepsinya mengenai pembagian resiko tidak ada perbedaan yang signifikan

30 Analisis Persepsi Pemilik dan Kontraktor Terhadap Pembagian Resiko dalam Kontrak Unit Price (Indra Suharyanto) 


\section{KESIMPULAN DAN SARAN}

\subsection{Kesimpulan}

Dari hasil analisa persepsi pemilik dan persepsi kontraktor terhadap pembagian resiko dalam kontrak unit price dapat disimpulakan :

1. Pemilik dan kontraktor mempunyai persamaan persepsi mengenai tanggung jawab yang sama besar mengenai resiko lingkungan dan resiko syarat-syarat kontrak.

2. Pemilik dan kontraktor berbeda persepsi mengenai resiko desain perencanaan dan resiko finansial. Pemilik beranggapan resiko desain perencanaan menjadi tanggung jawab pemilik dan resiko finansial menjadi tanggug jawab bersama, sedangkan kontraktor beranggapan resiko desain perencanaan menjadi tanggung jawab bersama dan resiko finansial menjadi tanggung jawab pemilik.

3. Pemilik mempunyai tanggung jawab yang besar mengenai resiko politik, sosial, ekonomi dan resiko force majeure, sedangkan kontraktor mempunyai tanggung jawab yang besar mengenai resiko perusahaan, resiko logistik dan resiko pekerjaan konstruksi.

4. Dari uji Mann Withney didapat nilai signifikan 0,880 yang berarti pemilik dan kontraktor dalam persepsi mengenai pembagian resiko dalam kontrak unit price tidak ada perbedaan yang signifikan.

\subsection{Saran}

1. Dalam kontrak dengan sistem kontrak unit price hendaknya menggunakan metode pelakasanaan yang baik dan selalu dilakukan evaluasi agar dapat diketahui bila terjadi penyimpangan-penyimpangan lebih dini sehingga dapat meningkatkan efisien dan efektifitasnya.

2. Dalam kondisi perekonomian yang kurang mendukung perlu kajian yang lebih terfokus terhadap pelaksanaan pekarjaan yang macet (terhenti di tengah jalan) serta dicari solusi pemecahan sehingga tidak saling merugikan.

\section{DAFTAR PUSTAKA}

Darmawan H, 1996, Manajemen Resiko, Bumi Aksara, Jakarta.

Ervianto, W.I, 1998, Kontrak Konstruksi dan Analisa Kuantitatif Tuntutan Biaya Overhead, FT UAJY, Yogyakarta.

Fisk, E.R, 1997, Construction Project Administration, Prentice Hall, New Jersey.

Haryono, P, 1996, Mengolah Data Statistik dengan SPSS / PC+, NI-03, Andi Offset, Yogyakarta.

Kaming, F.P, 1998, Analisis dan Management Resiko pada Konstruksi, Program Pasca Sarjana UAJY, Yogyakarta.

Soeharto, Imam, 1996, Manajemen Proyek, Erlangga, Jakarta.

Shahab, H, 1996, Aspek Hukum dalam Sengketa Bidang Konstruksi, Djambatan, Jakarta.

Subiyakto, H, 1997, Statika untuk Bisnis, Bagian Penerbit Sekolah Tinggi Ilmu Ekonomi YKPN, Yogyakarta.

Uff, J, 1996, Construction Low, Sweet and Maxwell, London.

Wideman, R.M, 1992, Project and Risk Management a Guide to Managing, Project Risk and Opportunities, Project and Management Institute, PA, USA. 